\title{
EEN WOORD OVER AMBACHTSONDERWIJS EN ZIJNE DOELMATIGSTE ORGANISATIE.
}

Het is een gelukkig versebijnsel in de maatsebappij, dat elke publieke zaak zich mag verheugen in voor- en tegenstanders, en het ware te betreuren, indien er niet gevonden werden die, waar het een algemeen belang hetreft, daarvoor ten strijde trekken, of wederom anderen die, niet overtuigd van het nut, zich eveneens gaan wapenen om hunne zienswijze veld te doen winnen.

Een voorbeeld vinden wij in ons onderwijs, lager en middelbaar; zoo er ééne zaak is die zieb op bestrijders en verdedigers kan beroemen, dan is het deze. Ik wil niet beweren dat beide volmaakt zijn, dat er in de wetten waarbij zij werden geregeld niet iets bestaat wat voor verbetering vatbaar is, maar ik zeg toch: het is een nitstekend beginsel dat de grondslag is van die wetten; het "openbaar onderwijs" is een heerlijke zaak !... Natuurlijk, altijd als voorstander; want, hoor maar do bestrijders, hoor hen, hoe zij dat onderwijs brandmerken als een godsdienstloos onderwijs, en waarom?

Eenvoudig, omdat de wetgever het niet nuttig oordeelde, om de nog ewakke hersenen der toekomstige staatsburgers op te vullen met allerlei dogma's verre boven hunne bevatting verheven; orndat de wetgever het verderfelijk achtte dat op de school, die maatschappij in 't klein, de kiem van verdeeldheid en geloofeijver tusscben de zonen van het zelfde vaderland werd gelegd en daarom besloot dat het onderwijs zou worden gegeven met eerbiediging van ieders godsdienstige overtuiging. Toch hoort men nu dagelijks dat onderwijs aanvallen, en heeft men zelfs bij de begrootingsdebatton in 's lands vergaderzaal zware en $\mathrm{m}$. i. onthoudbare beschuldigingen tegen het middelbaar onderwijs hooren uitbrengen.... maar $i k$ bemerk dat ik zoo sprekende zoetjes aan mijn voorgenomen plan voorbijzie. Vergeving lezer, ik heb het plan ook over een zeker sourt van onderwijs te spreken, over een onderwijs dat in nauw verband 
staat met lager- en middelbaar, omdat het in vereeniging met beide moet dienstbaar wezen aan volksontwikkeling; over een onderwijs dat, hoewel jong, reeds even als het lager en middelbare, voor- en tegenstanders bezit, ja meer nog, dat ook te strijden heeft togen onverschilligen; maar dat or in zooverre van verschilt, dat de onverschilligen uit onbekendheid met de zark ontstaan spoedig zullen verdwịnen, on de tegenstanders van geheel ander allooi zijn dan zij, die schịnen te rreezen dat wanneer men op de school niet meer mag spreken over het leven en de daden van den stichter des christendoms, het Nederlandsche volk het recht verliest aanspraak le maken op den reeds ouden lof, een godsdienstig volk te zijn.

Gij hebt het misschion reeds geraden, of beter de titel aan het hoofd van mijn schrijren heeft het u reeds gezegd, dat ik wensçh te spreken over "ambachts onderwijs." Er is een tijd geweest dat de benaming „Hollandsch fabriekaat" gelijkluidend was met „deugdelijk fabriekast." Dat was de tijd van Hollands bloei; de Hollandsche nijverheid was alom vermaard, en naburige landen waren cijusbaar ann het nederige gemeenebest.

Het is schier onnoodig te zeggen, een ieder erkent onze achterlijkheid op vele punten van industrieel gobied, zoowel ten opzichte van eigen toestand vroeger, als voor de ons omringende volken, die vooral in sierlijkheid van fabriekaat en toepassing der kunst bij de nijverheid ons verre vooruit zijn gestreefd. Die achterlijkheid is aan vele oorzaken to wijten, waaronder ook het opheffen van de Gilden. Niet dat wij die in hun vorigen vorm van uitsluiting zouden terugwenschen, verre van dien, doch zij hadden bij vele nadeelen deze goede zijde dat men van de opleiding van den werkman tot kundig man in zijn vak meer werk maakte dan thans geschiedt.

Welnu, daarin moet verandering komen, Holland's oude roem moet weder te voorschijn treden en gelukkig wij zijn op weg. Er is een geneesmiddel voor de $k$ waal. Dat middel heet alweder onderwijs.

Het is vooral de toekomstige werkman die meer moet leeren dan eenvoudig handenarbeid, hij moet partij weten te trekken van een tal wetenschappen, vroeger slechts bij name aan den werkman bekend en waaronder ik in de eerste plaats noem handen regtlijnig teekenen, wiskunde, mechanica, natuur en scheikunde; maar dit is niet alleen voldoende: zijn voorstellingsvermogen moge zoodoende opgescherpt worden, hij moge vich 


\section{1}

rekenschap kunnen geven ran het hoe en waarom der dingen, hij zal aan dat alles moeten paren een rappe hand, en daartoe is noodig dat hij goed onderwezen wordt in het handwerk dat hij heeft gekozen, of liever - want van keuze kan men op dit punt helaas bijna niet spreken - waar het toeval hem voor heeft bestemd.

Dat onderwijs ontvangt hij, 't is overbekend, in de werkplaats, maar in de laatste jaren zijn er meer en meer op ervaring gegronde stemmen opgegaan, is er aangetoond dat zij slechte kweekplaatsen zijn en dat, wil men de welvaart der nijverheid bevorderen - waartoe in de eerste plaats vereischt wordt een bekwame werkende klasse - men dat onderwije aan die werkplaatsen moet ontnemen en overbrengen in de school. Sedert de invoering ran de wet op het middelbaar onderwijs die ook aan den werkenden stand een theoretiscb onderwijs verschafte, zijn die stemmen in aantal toegenomen, omdat men inziet dat de werkplaats aan dat onderwijs afbreuk doet, ja wat meer zegt, waar men somwijlen den leerling bespot wanneer hij bij het gebruik van zijn gereedschap denkt aan de toepassing van het geleerde, of aan een ouderen knecht wil verklaren hoe men in de praktijk van 't geen hij leert kan partij trekken; en zij die daarom het practisch onderwije aan de werkplaats willen ontnemen - en tot wien ook ik behoor - hebben volstrekt geen ongelijk. Hoor maar eens dien geroutineerden - altijd practischen werkman - wat kan hij zich boos maken over zulk een leerjongen die zijne wijsheid wil gaan uiten, wat zou zulk een droomer en wijsneus zich wel inbeelden? Hij deed beter zich met zijn werk te bemoeien. De patroon heeft groot gelijk dat hij hem des aronds niet vrij geeft voor het schooluur bijna heeft geslagen, waar dient die geleerdheid ook toe? al te gaêr gekheid; hij, oudere knecht, heeft ools school gegaan, zóó erg was het niet, maar toen bij de vier hoofdregels der rekenkunst machtig was, werd bij door zijn vader, die ook van die geleerdheid niets wist, naar een werkplaats gezonden, of beter, werd hem gelast naar eenig werk om te zien; wat suort werk dat deed er niet too, als er maar dadelijk iets bij te verdienen viel; en wie durft nu beweren dat hij zijn handwerk niet verstaat, ook zonder hulp dier vreemde wetenschappen? t zijn lasteraars die dat zeggen, enz.

Neen, dan houdt men meer van een jongen die 's avonils niet naar school gaat en die den spot drijft met een naar kennis stro. venden makker; wat is hij Hink bij de hand, hij weet de gunsi 
der oudere knechts te winnen, en als hij eens een buitenkansje heeft, koopt hij er geen boek voor, maar geeft het gaarne tot een zekere versnapering ten beste! Zie dat is waarlijk niet overdreven; ik heb met de werkende klasse lang genoeg verkeerd om voor de waarheid van hetgeen ik ternederschreef te kunnen instaan. Nog dagelijks kom ik met haar in aanraking, en telkens op nieuw wordt mij de juistheid er van bewezen.

Het is war, niet alle werklieden denken zoo over de vorming van den leerjongen, ik ken ook van die wakkere mannen die het betreureu dat zij in hunne jeugd niet meer geleerd hebben omdat de gelegenheid ontbrak, en die nu elke poging tot ontwikkeling toejuichon, maar het is een jammerinjke warhejd dat het getal van dezen luttel, zeer luttel is.

Zij vormen de minderheid in de werkplaatsen en kunnen darardoor weinig bijbrengen tot de goede opleiding der knapen, en wanneer gij bun oordeel vraagt, zoo zeggen zij ronduit, dat de werkplaats een alles behalve goede kweekplaatì is.

Wil men dus een goeden haudwerksstand vormen, dan is het noodzakelijk dat de leerjongens aan den invloed der gewone werkplaatsen worden onttrokken en overgeplaatat op inrichtingen waar men zich tot tark stelt hen voor hun toekomstig handwerk op te leiden.

Meer en meer verneemt men dan ook stemmen die aandringen op eene algemeene invoering van het practisch handwerksonderwïg. Niet allen echter worden door dezelfde beweegredenen geleid.

Er zijn die den in de werkplaatsen heerschenden geest veroordeelen en het daarom wenschen, maar ook anderen die in de invoering van het practisch onderricht een middel zien om iets te redden, en dat zijn zij die twijfelen aan de levenevatbarheid van ons middelbaar onderwijs, met name van onze burger dag- en avondscholen, bestemd volgens de wet van 2 Mei 1862 voor toekomstige handwerkslieden en landbouwers.

En zulke twijfelaars ziju er onder de voorstanders - de tegenstanders, ' $t$ is bekend, twijfelen niet, maar veroordeelen, of doen somwijlen nog ergere dingen - velen.

Zie, zeggen zij, iedere gemeente die meer dan 10000 zielen telt, is verplicht minstens ééne burger dag- en avondschool op to richten, en treedt nu eens die scholen binnen, gij denkt misschien cen groot aantal leerlingen te ontmoeten, maar gij vergist $u$, 't getal is alles behalve groot en die er zijn behooren niet tot den eigenlijken handworkestund, maar zullen opgceleid worden 
deze voor het leger, gene voor het kantoor. Op de banken wanr gij den toekomstigen timmerwan of smid denkt te vinden, kunt gij vinden den toekomstigen candidaat-notaris, koopman of onderwijzer.

En dat zijn nu de scholen waar men oen tercachtigen bandwerksstand wilde vormen! nu kunt gij eens zien hoo bet volk dien zegen wardeert!

In warheid, die verzuchting is niet geheel ongegrond; onze burger dag-en avondscholen verkeeren niet in bloeienden toestand en worden nog niet uitsluitend bezocht door hen waarvoor zij bestend zijn, maar zoû dat nu een reden zij̉n om aan hare levenevatbararheid te twijfelen?

Volstrekt niet - althrns naar mijne meoning. - Ik stel mij voor dat die scholen steeds in bloei zullen toenemen, maar dan zal eerst overwonnen moeten worden de bij den werkman heerschende denkwijze, dat handenarbeid en niets meer dan dit, voldoende is om te worden een bekwaam werkman, of wel, dat alle onderwijs hetwelk zich niet uitsluitend bezig houdt met het aanleeren der teekenkunst, zooals op de vroegere, thans voor het meerendeel in de burger-avondecholen opgeloste teekenscholen het geval was, niets te beteekenen beelt.

En die verkeerde denkwijze zal overwonnen worden, wanneer men maar geduld heeft.

Waarlijk, het is mij onbegrijpelijk hoe men kan twijfelen aan de leventvalbaarheid eener zaak, die in de meeste plaatsen van ons land nog maar eenige jaren bestaat. 't Spreekwoord onbekend maakt onbemind is ook hier van toepassing. Fens zal de tijd annbreken dat de werkende stand hat verkeerdo van hare meeniug inziet; bet kan wellicht nog eexige jaren aanhouden, maar geen nood, de scholen bestemd voor de toekomstige handwerkslieden zullen eens aan hun doel beantwoorden en dat tij.latip kan verhaast worden door de invoering van het professioneel onderwijs, 't geen vóór alles zal bijdragen tot een meer algemeen bezoek, on ook, en daar komt het juist op aan, invloed zal uitoefenen, op de vruchten van dat onderwije.

Ik beb meermaten reeds ben die met bet onderwija nan de burgeravondscholen belast zijn, huoren klagen over de loombeid van diegene hunner leerlingen die des daags in een werkplaats bezig zijn. Een alleszins bevoogd schrijver $\left(^{*}\right)$ wijst zonder er een verwijt van te maken, mede op die omstandigheid.

$\left(^{*}\right)$ Dr. D. J. Steyn Parvé in het October-noummer van de Economist jaargang 1872 , 
Hoo kan het ook anders, hoe kan men nog ijver en nauwlettendheid vragen van den knasp die den gehoelen dag werkzaam was in en buiten de werkplaats? Al verricht hij ook geen geregeld werk, al moet hij ook niet anders dan boodschappen doen, toch wordt hij vermoeid en het is geen wonder dat des avonds in een goed verwarmd lokaal, wanneer het matte lichaam een ocgenschijnlijke rust geniet, de geest stomp is, het leeren hem walgt en de slaap hem somwijlen overvalt.

Het is niet te verwonderen dat de knapen na den geheelen dqg verbonden te zijn geweest des avonds eene onweêrstaanbare behoefte aan vrijheid gevoelen, die oorzaak is dat zij aan eene wandeling met eenige makkers de voorkeur geven boven het zitten, somwijlen 3 a 4 uren, op de schoolbank, of wel, dat zij de ouders diets maken dat zij op de school toch niets anders leeren dan allerlei vreemde en onnutte zaken, en daarom maar voorstellen van het verdere bezoek te worden vrijgesteld.

Tooral daarom is de invoering van bet professioneel onderwijs ceue hoogst noodige zaak.

Hoe moet dat onderwijs ingericht worden, en is bet noodzakelijk dat de inveering door den Staat wordt ondernomen?

Ziedaar een tweetal belangrijke vragen dis ik zal trachten to beantwoorden.

Wat de invoering van Staatswege betreft, ik aarzel niet to verklaren dat volgens mijne zienswïze de Staat werkelijk verplicht is tot de invoering ran het professioneel onderwijs, omdat hij even goed als ieder burger afzonderlijk, belang heeft bij den hoogst mogelijken bloei der nijverheid en bij het zooveel doenlijk woren der armoede, en hoe zullen beide beter bereikt worden dan door eene flinke opleiding van den kern der natie, van de nijvere klasse bij uitnemendheid?"

Ik erken dat mijne meening door velen niet gedeeld wordt. Zoudt gij, zoo vraagt men, wenschen dat de Staal het handwerksunderwijs in uitgebreiden zin invoerde, of moeten enkele takken van nijverbeid worden voorgetrokken en daardoor eene ourechtvaardigheid geboren worden?

Ik beîm ten volle dat zoodanige wensch onzinnig zou zijn, en dat wij misschien aan het buitenland rechtmatige stof tot bespotting zouden geven, als wij scholen gingen oprichten ter vorming van kappers, slagers, koekbakkers enz., en terecht, want deze en zoovele takken van bedrijf mogen in de samenleving oumisbaar zijn, zij zijn betrekkelijk gemakkelijk te leepen, en 
worden niet in de eerste plaate vereischt tot den bloei der nijverheid.

Maar er zijn andere takken van bedrijf, die niet zoo gemakkelijk zijn aan te leeren, on bij wier bloei de Staat grooter belang beeft, omdat de welvaart er van afhangt, en dat zijn de bedrijven die zich onledig houden met de bewerking van hout en metalen in den meest uitgebreiden zin.

Welnu, het is niet onrechtraardig dat van Staatswege voor het onderwijs in de eerste beginselen dier bedrijven gezorgd wordt, evenmin als dat door den Staat wordt voorzien in 't onderwijs in de beeldende kunsten of dat er rijksinstellingen bestaan ter opleiding van ingenieurs, geneesheeren, advokaten, onderwijzers enz. Het is goed dat de Start zorgt voor de ontwikkeling der kunsten, want een volk dat geen kunstzin bezit, kan op den naam van beschaafde natie geen aanspraak maken.

Waar zou bet been, wanneer de Regeering niet zorgde dat wij bekwame geneesheeren, onderwijzers en ingenieurs deelachtig werden! volkomen juist, maar zeker is het dat bekwame werklieden even onmisbarr zijn als bekwame artsen.

Ontbraken de artsen, dan zouden wij weerlons zijn tegen ziekten en ongemakken en zoo er geen hulp van buiten kwam spoedig uitsterven; ontbraken de werklieden, dan zouden armoede en gebrek met den aankleve van dien hand over hand toenemen, het buitenland zou gevoed worden ten koste van eigen volk, of wel, vreemden zouden datgene moeten uitvoeren waartoe landgenooten niet in staat zouden zijn.

Daarom is het volgens mijne zienswijze de taak der regeering, te zorgen voor de opleiding van den jeugdigen werkman, en dat kan niet langs anderen weg dan door het oprichten van practische ambachtscholen. In de werkplasts kan zij niet ingaan, evenmin den patroon een methode van onderricht voorschrijven, want men zou alras ontwaren dat de patroons geen leerjongens meer zouden aannemen, en met volkomen recht, want de nijverheid moet vrij zijn, of men zou langs allerlei wegen de censuar trachten te ontwijken.

Die verplichting van den Staat wordt door velen ontkend, maar door niet weinigen voorgestaan.

Ir de Treede Kamer der Staten-Generaal is reeds meer dan eens op de invoering van practisch onderwijs angedrongen, ja wat meer zegt, bij de indiening en behandeling der tegenwoordige wet op het M. $O$. was het in de afdeelingen zelfs een punt van ernstige overweging. 
Sommige leden wenschten uit art. 13 te laten vervalien het onderwijs in de errste gronden der staathuishoudkunde, en daarvoor in de plants te stellen ,practische oefeningen met gereedschap en de draaibank"; de regeering was echter een ander gevoelen toegedaan en wilde de practische opleiding geheel aan de werkplaats overlaten; zij won het pleit, iets dat ik maar ten deelo betreur.

Ik zeg, ten deele, omdat ik geloof dat de staathuishoudkunde voor ons volk hoog noodig is in dezen tijd, nu men door onkunde maar al te geneigd is het oor to leenen aan allerlei valsche profeten.

Eene invoering van de practische oefeningen met inkrimping van enkele leervakken of vermeerdering van bet getal schooluren, zou mij wenschelijker voorgekomen zijn.

Die neder]aag heeft echter de voorstanders niet ontmoedigd, na dien tijd werd de regeering meermalen op de noodzakelijtheid der invoering van het professioneel onderwijs gewezen, maar ik geloof toch dat de zaak thans meer dan ooit tot de vrome wenschen behoort. Bij de jongste bebandeling der begrooting roerden de voorstanders dit punt niet weer aan.

. Misschien hebben zij er niet aan durven denken, bij het middelbaar onderwijs, dat zij zoo erbarmelijk hoorden belagen, een nieuw yak van onderwijs toe te voegen, of hebben zij de nvertuiging dat het weinig zal baten, daar de tegenwoordige Minister van Binnenlandsche Zaken met hen in gevoelen verschilt, hetgeen blijkt uit eene missive door Zijne Excellentie ten vorigen jare als antwoord gezonden an het Hoofdbestuur der Nederlandsche Maatschappij van Nijverbeid, 't welk zich naar aanleiding van een op het congres te Sneels genomen besluit tot $\mathbf{Z}$. M. den Koning had gewend, om Zijner Majesteits aandacht te vestigen op de iuvoering van het professioneel onderwijs van Rijkswege.

Het adres der Nijverheid werd door den Koning oun consideratie en advies gesteld in hauden van Zijne Excellentie den Minister van Binnenlandsche Zaben, die verklaarde zich met de beschouwing van de Maatsehappij niet te kunnen vereonigen.

„Wanneer men, zoo luidt 's ministers antwoord, let op de aauvankelijk verkregen uitkonsten in Amsterdam en Rotterdam, dan moge de oprichting van ambachtsscholen misschien wenschelijk zijn, boezeer ook hieromtrent verschil van gevoelen bestaat, doch dan blijft nog over, dat de oprichting van 's Rijkswege ongeoorloofd en in het algemeen onraadzaam is. 


\section{7}

"Ongerorlnofd, omdat bij de behandeling der wet op het mid. delbaar onderwijs in de Staten-Generaal uitdrukkelijk de vrang werd gesteld of onder de leervalken der voor den ambachtsstand bestemde scholen ook het professioneel onderwijs moest worden opgenomen?

"De toenmalige Minister van Binnenlandsche Zaken gaf hierop ten antwoord, dat het onderwijs aan de op te ricbten burger dagen avondscholen zich zou bepalen tot de voor den bandwerksstand noodige theoretische valken, maar dat de practische opleiding ann de werkplaateen werd overgelaten. De Staten-Generaal hebben met deze verklaring genoegen genomen, en derbalve mag worden anpgenomen dat dit stelsel als 't ware den grondulag der wet uitmakkt en dat het in strijd zou zijn met haren geest, indien van overheidewege professioneel onderwïs aan den ambachtsstand werd gegeren.

"Zelfe biedt de wet geen gelegenbeid aan om burger dạ- en avondscholen van Rijkswege to subsidieeren, terwijl hoogere burgerseholen door het Rijk worden opgericht of gesubsidieerd.

"Onraadzanm: omdat aan scholen door het Rijk opgericht in den rege! hooge eischen worden gesteld; bet eene ambacht heeft even reel recht om er te rijn vertegenwoordigd als het andere, althans de grens zou uiterst moeilijk te trekken zijn.

„Veel wordt geproduceerd wat, als het werk ran eerstbeginnenden, weinig waarde heeft; het Rijk zou deze producten tegen lagen prijs aan de markt moeten brengen en gaan wedijveren met de particuliere nijperheid. Dit bezwaar scheen mij, zegt de Minister, niet minder groot dan het vernietigen der vervaardigde voorwerpen, waardoor materiaal en werkkracht verloren gaan.

"Daarom kwam het mij wenschelijk voor dat dergelijke inrichtingen even als te Rotterdam, Amsterdam en Groningeu, door bijzondere personen of vereenigingen worden opyericht en bestuurd, als wanneer meer algemeene belangstelling mag verwacht worden. Waar de uitgaven te aanzienlijk zijn voor de particuliere krachten, daar kan, gelïk te Aunsterdam en Rotterdan geschiedt, hulp worden geboden door de Provineie en door de Gemente, welke laatste bij eene goede opleiding der ambachisslieden bet grootste belang heeft.

„Terecht - aldus vervolgt de minister - wordt in het adres opgernerkt dat de hulpmiddelen waarover groote gemeenten be. schikkeu kunnen, op de kleinere plaatsen ontbreken. Hiertegenover stagt echter dat het Rijk - indien tusschenkomst van Rijks- 
wege geoorloofúd of raadraam ware - evenmin ambachtsscholen zou kunnen oprichten overal, waar de wensch naar professioneel onderwijs wordt geuit, en dat, zooals te Groningen is gebleken, de zaak op eonvoudige wijze on met betrekkelijk weinig kosten kan geregeld worden in die gemeenten waar burger dag-en avondscholen bestan."

Tot zoover het advies van den minister.

Ik ontken niet, dat in 's ministers antwoord veel is wat slechts oogenschijnlijk als eene hinderpaal voor de invoering van het professioneel onderwijg van Rijkswege kan worden beschouwd, en waarmede ik mij niet kan vereenigen.

Dat is, onder meer, het geval met de "ongeoorloofdheid" dio haren grond zou vinden in de dasdzaak dat ruim 10 jaren geleden de Staten-Generaal berustten in de verklaring van minister Thorbecke, „dat de practische opleiding van den handwerksman aan de werkplaats zou worden overgelaten." Ik vraag: wanneer nu in 1874 of in '73, want van dien tijd dagteekent het antwoord van den tegenwoordigen minister, blijkt dat de verklaring in 1863 door Thorbecke gegeven niat de juiste is, of wanneer, wat mugelijk is, de toestanden in 1863 en 1873 zoodanig van elkarder verschillen, dat hetgeen toen niet wenschelijk bleek te 2 ijn, thans roodig inoet worden geacht, of het dan niet geoorloofd zou zijn eene wetsverandering of uitbreiding toetepassen?

Wat verder het recht der ambachten om in het stelsel van protessioneel onderwijs te worden opgenomen betreft, uit een rechtsoogpunt is "de bewering van den minister volkomen juist, waar let is de vraag of alle ambachten behoefte bebben asn practiach schoolonderricht niet alleen, maar ook of zij er voor gesehikt zijn.

Het grootste bezwaar, hierin ben ik het volkomen met den minister eens, zouden de geproduceerde voorwerpen opleveren, oudat het werk van eerstboginnenden weinig waarde heeft; daar staat echter tegenuver dat men van bet werk der meergevorderde leerlingen nog al partij zou kunnen trekken, wanneer ingevoord werd het voorstel door den heer Boersema, directeur der ambachtschool te 'B Hage, gedaan (*) dat nl. bij uitbestedingen de annnemers de verpligting werd opgelegd eenvoudige zaken an deze of gene ambachtschool te moeten laten vervaardigen

Het is waar, men zou dan allicht het verwijt hooren dat zoo-

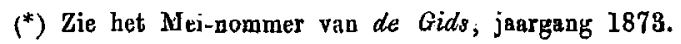


doende aan de particuliere nijverheid afbreuk werd gedaan, maar zou zoodanige maatregel onrechtraardiger zijn dan bijv. het laten werken in de gevangenissen?

It beb gemeend deze korte beschouwing van 's ministers antwoard te moeten nederschrijven, om aan te toonen dat tot op heden van de regeering in zake het oprichten van ambachlsscholen weinig to verwachten is.

En zal men daarin nu maar berusten als "die geen bope hebben" of wel zullen de voorstanders van het professioneel onderwijs eene afwachtende houding moeten aannemen?

Dat zou waarlijk te erg zïn; het standpunt ' $t$ welk de regeering in deze zaal meent to moeten innemen is voor ons geen reden, om de banden in den schoot te leggen, want het geldt hier eene zaak van even groot belang als elk ander onderwijs.

Artikel 194 der Grondwet bevat de schoone bepaling dat de Staat de verplichting om overal voldoend lager onderwijs te verschaffon op zich neemt; de wet op het middelbaar onderwijg is in het leven geroepen om aan het volk ontwikkeling en beschaving deelachtig te doen worden; welnu, laten wij, leden van dien staat, ook aan die ontwikkeling medewerken door bet zoo mogelijk a]gemeen invoeren van ambachtsonderwijs, want dat is zoo noodzakelijk dat ik zonder aarzelen deze stelling uitspreek: „in iedere gemeente waar volgens de wet op het $M$. $O$. eene burger dag-en avondachool moet bestaan, niet alleen, maar overal waar behoefte aan eene grondige opleiding der handwerkslięden bestaat, moet opgericht worden eene ancbacbtaschool."

Ik ontreins mij niet dat bij bet lezen dezer stelling de tegenstanders van het professioneel onderwijs misschion zullen glimlachen over zoodanige "ntopie", en menig voorstander zal zeggen dat zij onmogelijk uitvoerbaar is.

Ik hoop evenwel het tegendeel te bewijzen.

Ik zal daartoe mijne zienswijze over de organisatie van het ambachtsonderwijs ten beste geven, van dat underwijs waarvan boewel jong, reeds gezegd wordt, dat het zoo verbazend veel geld kost.

En in warheid die klacht is niet ongegrond; om ambachtsscholen zooals bijv. te Amsteriam, Rotterdam, 's Gravenhage en Arnhem bestaan, in wezen te bouden, zijn jaarlijks groote sommen benoodigd, als een gevolg van bet onderwijs dat er wordt gegeven, en dat uit een practisch en theoretisch gedeelte bestaat. Die uitgaven zouden aanmerkelijk minder zijn indien men de theorie 
\%oovel doonlijk achterwege liet. Men versta mij wel; ik wensch geen uitsiuitend practisch onderricht; $i k$ ben er tegen dat or alleen "handige" werklieden worden gevornd; ik wil de wetenschap volstrekt niet in ballingschap zenden, maar wat ik wensch is dit: dat de voorstanders van het professioneel onderwijs de theoretische vorming van den werkenden stand aan den Staat overlaten, zooals deze omgekeerd de nijverheid wil belasten met het practisch onderricht.

En dat is nu volstrekt geen weêrwraak, integendeel, ik geloof dat daardoor het doel van den wetgever bevorderd zal worden; deze toch heeft aan elke gemeente boven de 10000 zielen de verplichting opgelegd minstens eene burgerdag- en avondschool-op te richten, en gaf alleen het recht van dispensatie voor de eerste indien het blijkt dat eene burger-avondschool voldoende in de behoefte voorziet.

Dank zij de wet op het M. O. is dus iedere zoodmige gemeente verplicht te zorgen voor het theoretisch onderwijs van den handwerksstand en wanneer men art. 13 dier wet nagaat, kan men zonder overdrijving dat onderwijs voldoende heeten. Nu begrïp ik niet de nondzakelijkheid dat de ambachtescholen in concurrentie moeten treden met de buryerdag- en avondscholen, door nl. ook theoretisch onderwijs te geven.

Nog eens! ik wensch de theorie in 't geheel niet uittesluiten, maar ze zooveel doenlijk te verwijderen van de ambachtsscholen, waar handwerksonderwijs het voornaamste moet zijn.

Wiskunde, natuurkuude, hand en rechtlijnig teekenen, behooren naar mijue meening evenmin als lager- of herhalingsonderwijs, te huis op de ambachtsscholen. Het eerste moet overgrelaten worden aan de burgerdag- en arondscholen waar zij volgens de wet onderwezen moeten worden, en als onze leerjongens op de lagere school zoo weinig geleerd hebben, dat men om er iets goeds van te vornen dat onderwije moet voortzetten of herhalen, m. a. w. wammeer ons lager onderwijs niet voldoende blijkt te zijn, dan legge men, "oo als Dr. Steyn Parvé terecht beett geøegd "den vinger op de wonde, opdat de middelen ter genezing worden angewend."

Eene algemeene ontwikkeling, ziedaar het hoofddoel der wet op het M. O.; de in art. 13 opgenoemde valsken zijn nuttig voor iederen handwerksman en niet het minst voor hen, voor wien wij practisch schoolonderricht wenschen.

Aan de ambachtsscholen moet evenwel handenarbeid het eerste en voornaamste zijn. 
Die handenarbeid, ziedaar een struikelblok, neen ziedaar een punt waarop èn voor- èn tegenstanders wijzen, omdat men van oordeel is dat het ééne bedrijf niet ten koste van het andere mag voorgetrokken worden, dat alle bedrijven even veel recht hebben. Door nogmaals op mijne opinie omtrent dit punt neder te komen, zou ik wellicht van noodel ooze herbaling beschuldigd worden; dat zij echter juist is blijkt uit de omstandigbeid dat de leorjongens geplaatat bij die bedrijven die ik practisch onderwijs toewensch, het meest gebruik maken van het onderwijs op de bestaande burgerscholen, 't geen blijkt uit het reeds genoemd schrijven van Dr. Steyn Parvé, die mededeelt dat in $\mathbf{1 8 7 2}$ op de burgeravondscholen en daarmede gelijk te stellen inrichtingen 2753 leerlingen die reeds een beroep uitoefenden, aanwezig waren; van dezen waren:

1238 timmerlieden, schrijnwerkers, meubelmakers, wagenmakers.

388 smeden, geweermakers, instrumentmakers, koperslagers.

189 steenhouwers, metselaars, loodgieters.

138 beeldhouwers, stucadoors, goudsmeden, graveurs, lithographen.

229 schilders, glazenmakers en verlakkers.

50 bouwkundigen.

322 die een ander bedrijf uitoefenden dan de hier vermelde, en eindelijk 199 kweekelingen, onderwijzers, kantoorbedienden of klerken.

Ziedaar eene niet te verwerpen basis voor de keuze der vakken die in het professioneel onderwijs moeten opgenomen worden; hout- en metaalbewerking nemen den voorrang in, wel een bewijs dat zij, meer dan eenig bedrijf, recht hebben om bij de keuze van het onderwijs aan de ambachtsscholen in aanmerking te komen.

Dat onderwijs wensch ik opgedragen te zien aan geheel praktische scholen en aan geheel practische mannen, onder ééne voorwaarde, dat $\mathrm{nl}$. de leerlingen ook theoretisch, buiten de ambachtsschool, onderwezen worden.

Daardoor zal aan de tegenstanders een argument dat niet het minst weegt, ontnomen worden, nl. de hooge kosten.

Voor bet theoretisch onderwijs zijn, wanneer bet in de behoefte voorzien zal, kostbare hulpmiddelen en lokalen noodig; het practische kan met minder volstaan, ja voor een groot deel zelf in zijne behoette voorzien, zoodat invoering $\nabla a n$ regeeringswege niet juist noodzask is.

Medewerking door subsidiëering van het rijk, de provinciën of gemeenten is natuurijk niet te verwerpen, evenmin als ik het. 
afkeur dat, zooals b. P. to Rotterdam geschiedt, gemeenten die volgens de wet verplicht zijn tot het oprichten van eene burger dag- en avondschool, daarvan vrijstelling vragen en dan als het ware eene overeenkomst sluiten met eene bestaande of opterichten ambachtschool, deze ruim subsidieëren, en daarvoor in ruil verlangen bet geven van theoretisch onderwijs, waardoor als het ware tweeërlei inrichtingen in één gebouw en onder ééne leiding aanwerig zijn.

Op die wijze is natuurlijk theoretisch onderwijs op eene ambachtsschool ook op zijne plaats, maar overal waar om versehillende oorzaken die toestand niet in het leven kan worden geroepen, moet men zich maar uitsluitend bij het practiseh gedeelte bepalen, en het onderwijs in de theorie overlaten aan de gemeenten die daartoe verplicht zijn.

En het oprichten dier geheel practische scholen is waarlijk niet zoo bezwaarlijk als men wellicht zou denken, wanneer men maar zorgt voor een goed begin en niet direct eene te booge vlucht neemt door in het begin verschillende vakken te onderwijzen, want het is oneindig beter eerst eene goede. school voor één bepaald rak te hebben en langzamerhand aan hare uitbreiding te werken, dan op eens alles te willen. Wil men ambachtsscholen oprichten dan moet men, zooals ook werkelijk geschiedt, de medewerking der gegoede klasse inroepen; maar oprichten is alleen niet genoeg, de zaak moet blijven bestaan, moet langzamerhand uitgebreid worden en dartoe is voortdurende medewerking een vereischte.

Waar men nu begint met bet geven van onderwijs in eene tak van nijverheid heeft men tweeërlei voordeelen, eerstens zijn de kosten voor oprichten niet zoo groot als bij dadelijke toepas. sing van meerdere bedrijven, en ten tweeden kan men de aanwezige hulpmiddelen voor dien éénen tak aanwenden, dạardoor des te spoediger gunstige resultaten aanwijzen waardeor de belangstelling van het publiek wordt gaande gehouden en aangewakkerd, iets wat bepaald noodig is tot trapsgewijze uitbreiding.

Om een en ander met een voorbeeld te bewijzen, zal ik zoo kort mogelijk gaan mededeelen de geschiedenis van de oprichting der practische ambachtsechool te Groningen, in de hoop dat de bekendheid daarvan misschien kan leiden tot navolging. Ik ben tot bet doen dier mededeeling uitmuntend in staat, daur ik als lid der commissie an wie de oprichting was opgedragen een Wurkzanm andeol in die zaak heb gehad. 
Het is reeds eenige jaren geleden dat door de hier bestaande Vereeniging van Industrieelen en werkbazen eene commissie werd benoemd tat het uitbrengen van een rapport omtrent de wenschelijkheid van het oprichten eener practische ambachtssohool; de zaak was besproken, en de Vereeniging die reeds getoond had zich de vorming van bekwame handwerkslieden aantetrekken, wilde trachton eene ambachtsschool in het leven te roepen. Van daar bet benoemen dier commissie, van wie men na hare benoeming niets meer hoorde dan na een tijdsverloop van ruim twee jaren, toen zij in een uitgebreid rapport als hare zienswijze to kenney gaf dat de zaak zoo goed als onuitroerbaar was.

Voor eene ambachtsschool werd, volgens de commissie, vereiseht een groot gebouw met uitgestrekte lokalen, kostbare hulpmiddelep en een talrijk personeel, waarvoor men jaarlijks belangrijke uitgaven zou moeten doen, getuige de school te Amsterdam die men tot voorbeeld had gekozen.

Die uitgaven, geloofde de Commissie, konden nimmer bestreden worden, daar het niet denkbaar was dat de ingezetenen van Groningen bij wien men zou moeten aankloppen, de noodige ondersteuning zouden verschatfen.

En men moest volstrekt de zaak niet te klein organiseeren; "beter niett, dan gebreksig!"

Dat begreep ook de Vereeniging, die daarom besloot, onder dankbetuiging roor de genomene moeite, zich met de conclusie der commissie te vereenigen.

Het invoeren van practisch onderwije zou dus behooren tot de rubriek „vrome wenschen," maar daar trad één lid der genoemde. commissie op, - een man van uitstekende practische kennis op bijna ieder gebied - om te verklaren dat hij, hoewel mede onderteekenaar van het rapport, zich niet had kunnen vereenigen met dat stuk en de daaruit geboren conclusie; volgens hem moest men in het klein beginnen, dan zou men kans van slagen hebben en kon men des te gemakkelijker tot uitbreiding geraken; het was wel is waar éclatanter wanneer men dadelijk een groot gebouw kon stichten warop, op de manier der oude godshuizen, de namen der stichters en bestuurders in gouden schrift prijkten, maar zoo iets was niet bepaald noodzakelijk om nut te sticbten, dat kon men even goed doen in een pakhuis of op een vlieringzolder.

De stem die zich ongeveer zoo deed hooren was een stem opgegaan uit de praktijk, geuit door een man, wiens naam door geheel ons land ook onder de mannen der wetenschap, een goeden 


\section{4}

klank heeft, en nu denkt men misschien dat, waar zoo iemand een middel aangeeft, men er naar luistert?

In vele gevallen ja, maar bier had men er immers tegenover staan het oordeel van de meerderheid eener commissie die het toch wel zou weten, die zelfs in Amsterdam had geinforineerd!

Toch waren er enkele leden die er op aandrongen de zaak door te zetten, en na langdurige discussie werd eindelijk besloten eene nieuwe commissie te benoemen, aan wie zou worden opgedragen het uitbrengen van een rapport omtrent de meest geschikte organisatie eener ambachtsschool.

Kort na hare benoeming verscheen de commissie reeds met een rapport warin zij als hare overtuiging uitsprak dat eene proefneming op kleine schaal, dat eene school waar in het begin slechts één bedrijf werd onderwezen verre te verkiezen was boven een uitgebreid stelsel, waarom zij na uiteenzetting der gronden voorstelde: het oprichten van eene ambachtsschool op kleine schaal, en voor het vak dat er "moest onderwezen worden de houtbewerking aanberal.

De bewerking van bout was door de commissie om velerlei redenen gekozen. Op den voorgrond had gestaan het feit, dat dit vak 't meest verbreidde maar minst gekende is, terwijl ook buitendien een werkman, onverschillig welk vak bij beoefent, die vaardig met het timmergerei kan omgaan zeer gezocht is.

Maar er bestond nog eene andere niet minder belangrijke reden; de houtbewerking was bij uitnemendheid geschikt om eene ambachtssehool op te richten, men kon met behulp der leerlingen spoedig en met met weinig kosten de school van allerlei gereedschappen voorzien, self help moest hier worden toegepast, en het voorgestelde vak zou uit zich zelf tot meerdere uitbreiding voeren. Spoedig toch zou men tal van vervaardigde voorwerpen bezitten waaraan smid en schilder het hunne moesten doen, weluu dan in werking gesteld een eenvoudige smidse en eveneens een lokaal ingericht tot schilderswerkplaats, en men zou alreeds in drie vakken onderwijs geven.

De uitgaven, die zoodanige inrichting vereischte, waren door de commissie breedvoerig besproken, waarvan de slotsom was, dat men in het eerste jaar ongeveer over $f 1200$ zou moeten beschikken kunnen.

Wanneer men, aldus was haar betoog, uitgaat van de onder. stelling dat bij de opening 10 leerlingen worden geplaatst, dan zou voor het benoodigde gereedschap - 't welk roor het meeren. decl aan de school zou worden vervardigd $-f \cdot 400$ benondigd 


\section{5}

zijn; terwijl de kosten van onderhoud, hieronder begrepen de belooning voor den met het onderwijs belasten werkman, en eene uitbreiding zoodanig dat aan het einde van het eerste jaar 20 leerlingen konden geplaatst worden, voor dat jaar op $f 800$ werden beraamd.

Die gelden wilde de commissie bijeenzamelen door giften in eens en jaarlijksche bijdragen; zij stelde voor dat de vereeniging zich per circulaire tot de ingezetenen zou wenden, hun bet belang van eene goede vorming der werkende klasse uiteenzette, om zoodoende tot medewerking uit te roodigen.

Het voorstel der commissie vond bij de meerderheid der leden ondersteuning. In eene korte maar krachtig sprekende circulaire. werd de Groninger burgerij. op het nut van ambachts-onderwijs gewezen, en voor dat onderwijs vroeg men bijdragen die ruime winst zouden afwerpen, omdat een ontwikkeld werkman voordeel geeft aan den werkgever; om tot die ontwikkeling te geraken is onderwijs bet radicaalste middel; lager en middelbarr onderwijs is in Groningen meer dan elders voor den werkman toegankelijk, maar naast die scholen moeten verrïzen ambachtaseholen en daarvoor vroeg men eene ondersteuning die gelukkig niet uitbleef. De commissie die zich persoonlijk bij de ingezetenen vervoegde mocht de voldoening smaken dat haar meer dan de gevraagde som werd toegezegd, en toen men zoover was gevorderd, besloot, de vereeniging tot de oprichting der ambachtsschool en werd zị werkelijk den 1n Januari 1872 geopend.

Die opening geschiedde zonder eenig ceremonieel; men had een. bovengedeelte van een pakbuis in eene der achterbuurten gebuurd, een eenvoudig doch bekwaam werkman tot onderwijzer benoemd, en dezen zag men in den eersten tijd dagelijks met een vijftal leerlingen juerig bezig om de school van het noodige te voorzien.

Dat getal leerlingen was in bet eerst gering, hetgeen veroorzaakt werd door dat velen die toelating vroegen, niet genoeg ontwikkeld waren om met vrucht de lessen aan de school voor toekomstige bandwerkslieden te volgen $\left({ }^{*}\right)$, maar klom allengs en is thans tot ruim dertig gestegen, die allen voor de houtbewer-

(*) Deze school werd in 1869 door het gemeentebestuur, daartoe aangezocht door de Vereeniging van Industrieelen en Werkbazen, opgericht, om daardoor jonge lieden die niet kunnen voldoen aan de gestelde eischen voor de burgeravondschool in de gelegenheid to stellen theoretisch onderwijs te ontvaugen. $\mathrm{Z}_{\mathrm{ij}}$ bezit een driejarigen cursus en het onderwijs omvat, hoewel minder nitgebreid, bijna al de vakken die aan de burgerschool onderwezen worden. Het schoolgeld bedraagt per wiuter-halfjaar twee guldeu.

ECon. 1874. 


\section{6}

king zijn alägetiomen, hetgeen natuurlït ook eene vêrimeerdering van het onderwijzers-personeel ten gevolge heeft gehad.

Dit deze bedrijfstak met oordeel was gekozen bleek spoedig, het was een lust de leerlingen bezig te zien; zij hadden in het eerst een gemiddelden werktijd van 8 uur per dag, iets dat later verminderd werd omdat men inzag dat een te lange werktijd den lust niet anwaklert.

A tlès is overigens ingericht als op een gewone werkplaats, met dit onderscheid, dat hier "werken" de boodscháp in, en wel een blijde boodsehap.

Toen de school reèds eenigen tijd bestond en, dark zij het degelijk onderwijs, reeds flink gevớrmde leerlingen aanwezíg waren, heb ik mij meer dan eens verbeugd over het opgeruimde gelaat van dien knaap, die, pas als leerling aangenomen; jjorig een zijner oudere medeleerlingen moest belpen bij bet verväardigen van een schaafbank; aan vreugde geen gebrek, het wordt zijn achaafbank, daar moet hij in 't verrolg bij stann te werken en darom is hij nu ook zon ijrerig bezig; jammer dat die linnen kiel die hij bon gré mal gré aan noet hebben hem eerst wat hinderlijk is, maar grooter dan dit laatste is de vrees dat de schaafbank niet de vereischte afmetingen zal krijgen, daarom gebruikt hij elk oogenblik zijn nieuwen maatstok waarop de voetmaat rergeten schijnt.

En als die schaafbank gereed is moet hij degelijk an het werk; eerst met eene kast voor zijn gereedschap en, als bij iets verder bomt moet hij allerlei gereedschap, zooals schaven, winkelhakion, schrijf- en kruishouten voor eigen gebruik maken, want dio kast moet ook verder aangevild worden; en dat wordt tijd ook, want tot zoolang moet hij telkens iets ter leen vragen van zijn buurman die het tevens moet gebruiken, daar hij juist bezig is zijn kast een fraaier aanzien te geven, hij moet or nl. een paneeldeur voor maken, dat is een buitenkansje, 't is een blijk van tevredentieid over die trap, door hem zoo uiterst netjes afgeleverd.

't Ging met die trap beter als onlangs met dien linnenbak, die in het eerst zoo monsterachtig was dat menige waschrouw er over zou hebben gelachen, maar die allengskens kleiner is geworden, doordien, hoe valk de onderwïzer het ook heeft gewezen, het niet lukken wou de zwaluwstaarten zuiver te maken. Dat gelinte door anhoudend oefenen, altijd met denzelffen natuurlijk steeds kleiner wordende bak, 't duurde wel wat lang, maar 't kwam toch terecht. 
Nu begrijpt then allicht dat de knáap juist met zijn paneel aan het werk moeilijk zijn gereedschap kan missen; buitendiei' staat hij het ook ongaarne af, 'het behoort hem, hij moet or zorg voor dragen, want bij weet dat wanneer de drie jaren die hij als leerling op de school moet doorbrengen verstreken zijn en hij goed opgepast heeft, dat stel gereedschap hem zal worden geschonken.

Wat verheugt hij zich reeds bij voorbaat, hij is dan dadelijk knecht en bezit een vulledig stel gereedschap!

Dadelijk kneecht worden, hieraan wordt, ik erken het, door sommigeǹ getwijfeld, mäar ik geloof dat ook die twijfel zal verdwijnen.

Of zou een knaap die drie jaren aani een werkbank staat en niet tot allerlei neven werkzaambeden is gedoemd, die niet wordt bekzuord als hem iets mislukt al gaat ook het materiaal verloren, en datardoor een zekere mate vañ zelfstandigheid verkrijgt, in die drie jaren niet beter ontwikkeld worden dan menig makker op een werkplaats in zes of acht jaren?

Dat doel beoogt men met de Groninger practische ambachtsschool, die niet zetelt in een fraai gebouw, die bet pakbuis thans beeft verlaten om te resideeren op de zoldering der voormalige stads-timmerschuur, daartoe door het gemeentebestuur afgestann. Ik had bijna geschreven loffelijk afgestaan, maar trok dat woord bij tijds terug, omdat ik in de gemeentelijke ondersteuning van duadanige inrichting niets meer zie dan plicht.

Het practisch onderwijs toch is eene zaik van publiek belang, bet zal degelijke werklieden vormen en den genadeslag geven aan het patuperieme, on omdat wering van het pauperisme op den weg ligt van de gemeentebesturen, moet ook deze tak pan onderwijg door hen worden ondersteund; er was ook trouwens niet anders te wachten ran eene stad als Groningen die reeds zooveel voor het onderwijg heeft gedaan en nog dagelijks aan zijne uitbreiding werkt.

Het practisch onderwijs zal degelijke werklieden vormen, die niet alleen zijn een sieraad voor bunnen stand maar ook een zegen voor de geheele samenlering.

Dat begreep ook zeker een der grootste industrieelen der Hunsestad; die daarom, ter gelegenheid van zijn zilveren huwelijksfeest asn de schéol eene som van duizend guldens schonk, met toezegging dat die gift jaarlijks zou worden herhasld; dat begrepen ook zeker een groot getal ingezetenen die zich verbonden om jaarlijks tot hare instandhouding bijtedragen en daardoor veroorzaakten, dat eene inrichting die in het eerste jasr reeds toonde wat zij eens zal worden, voor goed werd gevestigd. 


\section{8}

Ik geloof te mogen beweren dat deze inrichting xich in de meest doelmatige organisatie mag rerheugen, doordat hier bij betrekkelijk geringe uitgaven, prachtige resultaten verkregen worden.

Thans wensch ik nog een tweetal punlen te behandelen, en wel de rraag: voor welke klasse der maatschappij moet men de. ambachtsscholen oprichten en waar vindt men steeds voldoend. werk voor de leerlingen?

Wat het eerste punt betreft hoor ik reeds bij voorbat een. antwoord, 't welk mij zegt dat men de ambachtsscholen moet oprichten voor den werkman, en dat is volkomen juist, mits men altijd in het oog houdt, dat tusschen werklieden groot verschil bestaat.

De gegoede burger wiens zoon een ambacht leert om later patroon te worden, zegt aitijd: mijn zoon wordt werkman; on hij zal hem gaarne op eene ambachtssebool plaatsen. Ik beb daar volstrekt 'niets tegen, als men maar zorgt dat de zoodanigen er niet het meerendeel der leerlingen uitmaken; de operhand - in aantal natuurlijk - moeten hebbèn de knapen uit de eigenlijke volksklasse, zij die knecht willen worden noeten op de ambachtsschool gevormd worden. Daarom moet het onderwije gratis gegeven worden - iets dat in Groningen het geval is - en niet zuo als bijv. te Amsterdam en Rotterdam op $f 15$ en $f 5$ per jaar gesteld worden.

Dat kan de werkman niet betalen, hij moet ook reeds alle tijdelijke verdiensten van zijn op de ambachtsschool geplaststen zoon derven. Men zal misschien zeggen dat in Amsterdam, evenmin als te Rotterdam, de zoon van den behoeftigen werkman wordt uitgesloten, omdat do donateurs en leden die er eene zekere som betalen bet recht tot kosteloos plaatsen van een of meer loerlingen bebben, maar meu bedenke dat zoodanige plaatsing wisselvallig is niet alleen, maar ook moet beschouwd worden als eene gunst, ja meer nog, als eene aalmoes on dat werkt verkeerd en vernederend.

Plants op eene smbachtsschool betalende en niet betalende leerlingen, en gij zult zien dat zij zich splitst in twee klassen: leerlingen die vooruit weten dat zij patroon zullen worden, die daar reeds op pralen en somwijlen met trots nederzien op hun makker die wellicht eens bij ben zal aanvrayen om werk en anderen die weten dat vader en moeder reeds hunkeren naar den dag waarop bun zoon met eigen verdiend geld te huis zal koinen. Is het wonder dat de eersten somwijlen penigszins uit de hoogte op de laatsten nederzien, en dezen omgekeerd met zekere afgunst een kipm van wrevel inzuigen? 
Men zegge niet gij overdrijft, ,het zijn mar jongens," men weet toch wel dat het jongensgemoed voor zoodanige indrukken maar al te vatbaar is en daarom, de plaatsing op eene ambachtssechool moet geene gunst maar voor ieder toegankelijk, dus kosteloos uijn.

Willen zij die later patroon, opzichter of iets dergelijks wenschen te worden, dat onderwijs genieten, dan geen onderscheid, en kan men slechte een beperkt getal leerlingen plaatsen dan als regel de zonen uit de geringere volksklasse en als uitzondering de meer gefortuneerden, of wel men richte een afzonderlijken cursus voor de laatsten op.

Is dat onuitvoerbaar, welnu! laat de middenstand zijne zonen dan op de gewone werkplaats zenden, en den patroon dier werkplaats darrvoor eene zekere vèrgoeding geven waarvan een deel worde afgestaan aan een der knechts die zich met de opleiding moet belasten. De toekomstige patroon of opzichter zal dan zijn rak voldoende meester worden.

En nu de vraag: waar vindt men altijd werk voor de leerlingen? Waarlijk een belangrijke rraag, die zoo wat in de argumenten door de tegenstanders angevoerd nommer één is, en niet zonder reden, de werkzaamheden moeten een zuiver practisch en productief karakter hebben, alles wat naar knutselwerk zweemt moet zooveel mogelijk vermeden worden.

Maar daar hoort men stemmen opgaan die in dat productief karakter een schaduwzijde zien voor de nijverheid, die schade zal lijden door het werken voor particulieren.

Zij die zoo hunne stem doen hooren, kunnen zich ook niet vereenigen met een ander, niet productief stelsel, waarbij men de gemaakte voorwerpen weêr gaat sloopen, omdat zoo iets volgens hen eene verspilling van materiaal en werkkrachten is.

Dit lastate ben ik volkomen met hen. eens, meer nog, ik voeg er bij dat genoemd stelsel den ijver der leerlingen verdooft, omdat zij vooruit weten dat bet vervaardigde toch geen speciaal doel heeft; maar slechts zoo lang zal worden bewaard tot er behoefte aan materiaal of wel gebrek aan geschikt werk zal ontstan; eon gevolg hiervan zal zijn dat zij zich, trots het noodige touzicht, niet met de vereischio nauwgezetheid op de afwerking zullen toeleggen, waardoor het onderwijg veel van zijn waarde zal verliezen. Schenkt men hü echter een zeker vertrouwen bij het maken van voorwerpen die een bepaald doel hebben, dau zal men hunnen ijver eu nauwgezetheid asnwakeren.

Maar nu komt meer bepaald de vraag hoe altijd rọldoend werk 
kan rerkregen worden. Ik heb reeds gezegd en door het voorbeeld der Groninger school er op gewezen, dat deleerlingen veel kunnen vervardigen wat op de inrichting in gebruik kan worden genomen, masr bij eenige uitbreiding bomt ook biersap een einde, dasr de behoeften der school niet evenredig aijn aan de productieve kracht der leerlingen, hetgeen op het oogenblik to Groningen het geval is.

Men zal dus nar ander werk moeton omzien en de leerlingen allerlei voorwerpen bij wier samenstelling iets te leeren vait laten maken. Deze voorwerpen zal men zooveel mogelijk van de hand trachten te zetten, of wel zich tot de patroons weuden met verzoek om, natuurlijk tegen billijke rergoeding, eenvoudige werkzanmheden door de jongelieden der school te laten vervaardigep, hetgeen o. a. te Rotterdam geschiedt. Maar zoo als gezegd is, dạar hoort men stemmen opgaan die beweren dat dagrdoor de nijverheid wordt benadeeld; ik geloof echter die bewering als onjuist te mogen kwalificeeren.

Zij zou het dan eerst doeu, wạnneer men yoor de patroons het werk teged een ongeëvenarden spotprijs of wel zonder eenige tegecoetkoming rerraardigde. Zoolang dat niet plaats heeft, zal do nijverheid weinig afbreuk worden gedaan, want do jongelieden der ambachtsschool zouden, bij een patroon geplaatst, toch ook werkzaambeden verrichten, al is het dan ook niet in die mate als nu zij aan de school werken.

Aangenomen echter dat het werken voor particulieren of patroons aan de nijverbeid eenige schade berokkent, zou dat nu zoo erg zijn om daardoor het oprichten van ambachtscholen te wraken? Aan bet Instituut voor Duofstommen te Groningen bestaau werkplaatsen waar 0 . a. allerlei boutwerk wordt vervaardigd, en menigeen, die eenig vaatwerk of iets anders noodig beeft, gaat naar die inrichting om pet daar te koopen, niet omdat het er goedkooper is dan bij een ondernemer van dusdauig bedrijf het tegendeel is waar - maar alleen om de inrichting te bevoordeelen en de ongelukkigen die daar, verpleegd en onderwezen worden, de gelegenheid te schenken steeds volop werk to hebben. Die toestand bestaat sedert jaren en nog nimmer heb ik iemand een gegronde klacht hooren uiteu over de schade daardoor aan anderen berokkend.

Welnu, zoo zal bet ook wel gaan wet de ambachtscholen; zij die daar iets laten maken zullen dat minder doen om eigen gewin, dau wel om de inrichting te bevoordeelen, on wil men de particuliere nijverbeid ook ieto van dat voordeel guonen, dan volgo 


\section{1}

men het vourbeeld der Grouingur schuol, wạar alles moet worden verkocht door tusschenkomst van een in hetzelfde vak gepatenteerd persoon, die er desverkiezppdo zijne winst op kan nemen.

Ik ben aan het einde van mijn betoog, en hoop dat hetgeen ik in losse trekken heb nedergeschreven moge bijdragen om het practisch ambachtsonderwijs meer en meer ingang te doen vinden, iets dat hoog noodig is in een tijd als de onze, waarin maar al te veel valsche profeten opstan om een strijd te prediken tusschen arbeid en kapitaal, tusschen werkman en werkgever; een strijd die eens los zal barsten wanneer niet bij tijds gezorgd wordt dat onze werkende klasse bestaat uit mannen kloek van hoofd en rap van hand.

Daartoe wẹkt niets beilzạmer dan onderwịjs, het radicaalste middel om de sociale quaestie een vreedzame oplossing te wanrborgen. Maar theoretisch onderwijs alleen is hiertoe niet voldoende. Een helder hoofd moge het inzien dat de bestaande toestand niet verbeterd wordt door meetings en strikes, ook de vardige band van den werkman zal daartoe moeten bijdragen.

Wanneer door geringe verdiensten, gebrek de woning van den werkman binnenșluipt, dan zwijgt wel eens het gezond verstand en leent bij gretig het oor aan hen die van miskenning praten, maar dat zal niet het geval zijn wanueer hij moedig het hoofd kan bieden aan tegenspoed in zijn handwerk, en daartoe is het practisch onderwijs bij uitnemondheid geschikt.

Wanneer dat onderwijs algemeen wordt ingevoerd zal het pauperisme meer en meer verdwijnen; dan zullen er werklieden gevormd worden die door hunne bekwaamheden altijd werk on dus verdiensten bebben, die de lange winteravonden zullen gebruiken voor huiswerk dat er in menigte to vinden is in roorwerpen die nu uit den vreemde komen - men denke slechts agan de zoogenaamde Neurenberger artikelen - en daar roor een gedeelte worden vervaardigd door menschen die het als nevenhandwerk uitoefenen.

Uit den vreemde! ja daar is voor den Nederlandschen werkman inenig voorbeeld te trekken!

Men smaalt er altijd op dat er zooveel ingevoerd wordt wat hier ook wal kon gemakkt worden, maar men vergeet dat meu hier niet achter het gebeim van daar ginds is, dat verdeeling van arbeid hier nog bijna zoo goed als onbekend is, en laten wij het eens aan onzen werkman vragen, of bij ook zoo reislustig is als bijr, de bewoner van bet Schwarzwald, de maker van den 
bekenden Koekoeksklok. Onze werkman blijft het liefst te huis, starende op het werk dat zijne vaderen gedaan hebben, terwijl de eenroudige klokken- en speeldoosmaker ran het Schwarzwald niet schroomt yreemde landen te bezoeken.

Ook dat moet en zal bij ons anders worden, wanneer wij naar behooren zorgen voor de opleiding onzer knapen tot leergierige en vaardige werklieden die gerust naar het buitenland kunnen gaan, omdat hunne bekwaamheid hun ook daar brood zal verschaffen" $\left(^{*}\right)$.

En daartoe moeten er ambachtsscholen verrijzen tot heil van den werkman, tot nut van het algemeen ( $\dagger$ ), want ik onderschrijf volgaarne wat de reeds genoemde commissie voor de Groninger ambachtsechool in hare eerste circulaire zegt:

„Wordt de werkende stand bekwamer dan zal de arbeider hooger loon ontvangen terwijl de werkgever voor dezelfde, ja zelfs voor geringer uitgaven, meer en beter werk zal ontvangen."

Hooger loon en beter werk, ziedaar de vruchten van het ambachtsonderwijs, en wie zou daar niet aan willen medewerken?

Voorzeker een ieder die belang stelt in den stand die zulk cene voorname rol in de matschappij vervult!

Voorzeker elk en een iegelijk wien de bloei onzer nijverbeid, dat is de bloei van ons volk ter harte gaat!

En daarom, voorstanders van 't onderwijs en van het practisch onderwijs in het bijzonder; opgestaan als één mau ter bevordering onzer welvaart.

Eens wanneer de vruchten van het ambachtsonderwijs langzamerhand te roorschijn treden, zullen de tegenstauders bondgenooten worden, en zal niet meer gelden wat eenige jaren geleden naar waurheid werd verkondigd, dat "ons volk is achterlijk en slap."
Groningen, Augustus 1874.
J. J. HAHN.

(*) Men zou den lust voor het bezoeken van vreemde landen o. a. kannen aanwakkeren door aan verdienstelijke leerlingen der practische ambachtsschool, na het verlaten der inrichting, eenig subsidie gedurende zekeren tijd te verleenen, onder voorwaarde dat zij dien tijd in het buitenland als gezel moesten doorbrengen nadat zij eerst gedurende eén of twee jaren in ons land in een of meer werkplaatsen werkzaam geweest waren.

( $t$ Waar geene burgeravondscholen bestaan, dus in kleine gemeenten, richte men ze eveneens oj, maar zie tevens aan zoodanige inrichting iemand te verbinden die de leerlingen eenige uren in de week theoretisch onderwijs geeft; 't is warr, de wet op het middelbaar onderwijs verbiedt het geven van onderricht in de vakken bij die wet genoemit ann niet-geexamineerden, maar tal van onderwijzers der lagere school bezitten genoog bekwaambeden om dusdanig theoretisch onderwijs te geven. 